\title{
Lecturer Performance Factors in Private Universities in Bandung City
}

\author{
Ratih Hadiantini (Corresponding author) \\ Faculty of Economic and Business, Universitas Informatika dan Bisnis Indonesia \\ Soekarno - Hatta St. No. 643, Sukapura, Kiaracondong, Bandung, Indonesia \\ E-mail: ratih.hadiantini@unibi.ac.id
}

Suka Prayanta Pandia

Faculty of Informatics, Universitas Informatika dan Bisnis Indonesia

Soekarno - Hatta St. No. 643, Sukapura, Kiaracondong, Bandung, Indonesia

E-mail: suka.pandia@unibi.ac.id

Emil Robert Kaburuan

Faculty of Informatics, Universitas Informatika dan Bisnis Indonesia

Soekarno - Hatta St. No. 643, Sukapura, Kiaracondong, Bandung, Indonesia

E-mail: er.kaburuan@unibi.ac.id

Received: Oct. 3, 2017 Accepted: Oct. 24, 2017 Online published: Oct. 28, 2017

doi:10.5296/ijhrs.v7i4.12079 URL: https://doi.org/10.5296/ijhrs.v7i4.12079

\begin{abstract}
Nowadays, private universities in west Java, especially in Bandung city, grow and develop fast. Educators are the most important aspect to improve higher education quality. We are talking about lecturers in this case. Government rule says in teacher and lecturer act No. 14 year 2015 that lecturer is professional educator and scientist who transform, develop, and propagate science, technology, and art through education, research, and society dedication. Lecturer is educator who has important role in transforming learners, and lecturer has to have good qualification of academic and character. Lecturer is prosecuted to present good
\end{abstract}


performance. A high lecturer performance influences a higher education quality. This research is aimed to figure out the factors that influence lecturer performance. Performance factors of lecturer include experience, skill, age, sex, education, work period, responsibility, work satisfaction, perception, motivation, leadership, fee, supervision, and work condition (Robbins S P, 2011). There are seven (7) factors, in this research, that influence lecturer performance in learning process in private universities in Bandung city such as age, education, work period, work motivation, work satisfaction, fee perception and supervision perception. The result of the research says $X_{1}$ variable (age) influences in the amount of $0,069, X_{2}$ variable (education) influences in the amount of 0,$571 ; X_{3}$ variable (work period) influences in the amount of 0,$034 ; X_{4}$ variable (work motivation) influences in the amount of 1,$185 ; X_{5}$ variable (work satisfaction) influences in the amount of 0,$554 ; \mathrm{X}_{6}$ variable (fee perception) influences in the amount of $-0,38 ; X_{7}$ variable (supervision perception) influences in the amount of 0,209 .

Keywords: lecturer performance, performance, performance factors, private university

\section{Introduction}

University is one of educational institution which produces qualified human resources. Government rule No. 30/1990 explains that university is aimed to prepare learners to be citizen who have academic or professional ability which can apply, develop, and create science, technology and art. There are some struggles to achieve the dream to perform qualified higher education. It needs a massive improvement towards the aspects; lecturer is the most important aspect to improve the quality of higher education.

Christianingsih (2011), in her research, declares that lecturer condition in private university in Bandung city is divided into three sections based on the educational background such as undergraduate (S1) $51.65 \%$, Master program (S2) 38.85\%, and doctoral program (S3) $12.50 \%$. Lecturer determines the graduates and the quality of institution. Lecturer, moreover, is prosecuted to perform a good performance. A high lecturer performance will influence the quality of university. Some aspects to influence lecturer performance are work experience, knowledge mastery, motivation, leadership, work environment and lecturer's satisfaction towards the institution.

Learning process is one of the processes which contains some actions both from educators and learners in educational situation to achieve the goal (General Director of higher education, 2011). Lecturer ability to perform learning process is the main aspect to be supervised to keep the quality of university. The supervision can be done by the lecturers themselves, leader (the chief of study program), or learners through their perception (Rohani A. and Ahmadi, A., 1999).

It is very interesting to supervise the performance of the lecturer. Performance is someone's achievement regarding to their assignments. Performance supervision is used to check, analyse and evaluate employee's performance (Marwansyah, 2014). Lecturer attitude to accomplish the achievement is influenced by some individual factors, for instance, psychology and organization (Robins S.P, 2011). 


\section{Literature Review}

\subsection{Defining Performance}

Performance is the result of attitude (Amstrong, 1999). The definition of performance is related to the result of work and attitude. Performance, by means of attitude, is human activity which is directed to organization task.

Mundarti (2007) describes that performance is employee's achievement in completing the job. Performance, in other words, is things done by employee. Performance is influenced by personal factor; nevertheless, other factors influence the performance such as system, situation, leadership or team. The factors that influence individual performance are ability, motivation, support, work situation and the organization relationship (Mundarti, 2007).

\subsection{Performance Appraisal}

Performance appraisal is formal system to check, analyse and evaluate individual performance or group performance. Performance is the achievement of someone related to the assignments. Performance, in the other words, is the combination of work result and competence. Amstrong (1999) clarifies that performance appraisal is aimed to measure the performance fairly and objectively based on work requirement which improves and identifies specific development objectives. In addition, performance appraisal can develop carrier objective thus employee can adapt with dynamic organization objective.

\subsection{Measuring Performance}

There are three important variables to measure a performance, for example, attitude (process), output (a product of an activity/ program), and outcome (value added or effect of an activity / program). Attitude which comes from the output and outcome (value added) is a variable which cannot be separated and depend one another (Mundarti, 2007).

Measuring performance covers an activity to determine some measurements or performance indicator which gives information for public sector to monitor the performance thus it can produce output and outcome for the society. Measuring performance is useful to help work unit manager in monitoring and repairing the performance, and it can focus on the organization objective to fulfil the public accountability demand (Mundarti, 2007).

\subsection{Measuring Performance Technique}

Simon, in Mundarti (2007) states that anyone who understands and knows how to appraise employee can measure the performance, for instance, inferior appraisal by superior, superior appraisal by inferior, group/ team appraisal, self-appraisal, external appraisal, and multisource appraisal (360-degree feedback).

\subsection{Lecturer Performance}

National Department of Education (2004) states that lecturer performance is the ability of lecturer to perform the assignment in order to complete the job. Performance, in other words, is work presentation, work implementation, work achievement, or work result (LAN, 2004). 


\section{Macrothink}

International Journal of Human Resource Studies

ISSN 2162-3058

2017, Vol. 7, No. 4

Smith (1982), in line with National Department of Education, affirms that "performance is the output drive from processes, human or otherwise". It can be said, in other words, that performance is the result or the output of a process.

To explain more about lecturer performance, Blazey, et al (2009) explains that criteria of education performance is aimed to (1) improve performance, capability, and educational output (2) ease the communication and exchange information about the best educational practice of some institutions, and (3) be the tool to comprehend and improve educational institution performance, likewise to be the guidance of strategic planning.

\section{Methodology}

This research uses observational method. It means that this research only does the observation without giving any intervention to the variables (Suparyanto, 2010). This research is analytical description which reveals some factors that influence lecturer performance in performing learning processes. This research, in addition, employs cross sectional approach in which dependent variable and independent variable are taken once at the same time. This research has four private universities in Bandung city as the research data. The four private universities are in the same area of coordination, that is, private university coordination area IV. The data of private universities are concealed to keep the respondents' secrecy.

The instrument of the research is questioner. The questioner has been used before by the previous research, that is, "Lecturer Performance Factors" (Mundarti, 2007). The questioner is used to appraise lecturer performance in learning process, age, education, work period, work satisfaction, fee perception, and supervision perception.

The variable in this research is divided into two variables, dependent variable and independent variable. The dependent variable is lecturer performance in learning process, while independent variable in this research are age, education, work period, work motivation, work satisfaction, fee perception, and supervision perception. Figure 1 displays the research framework. 


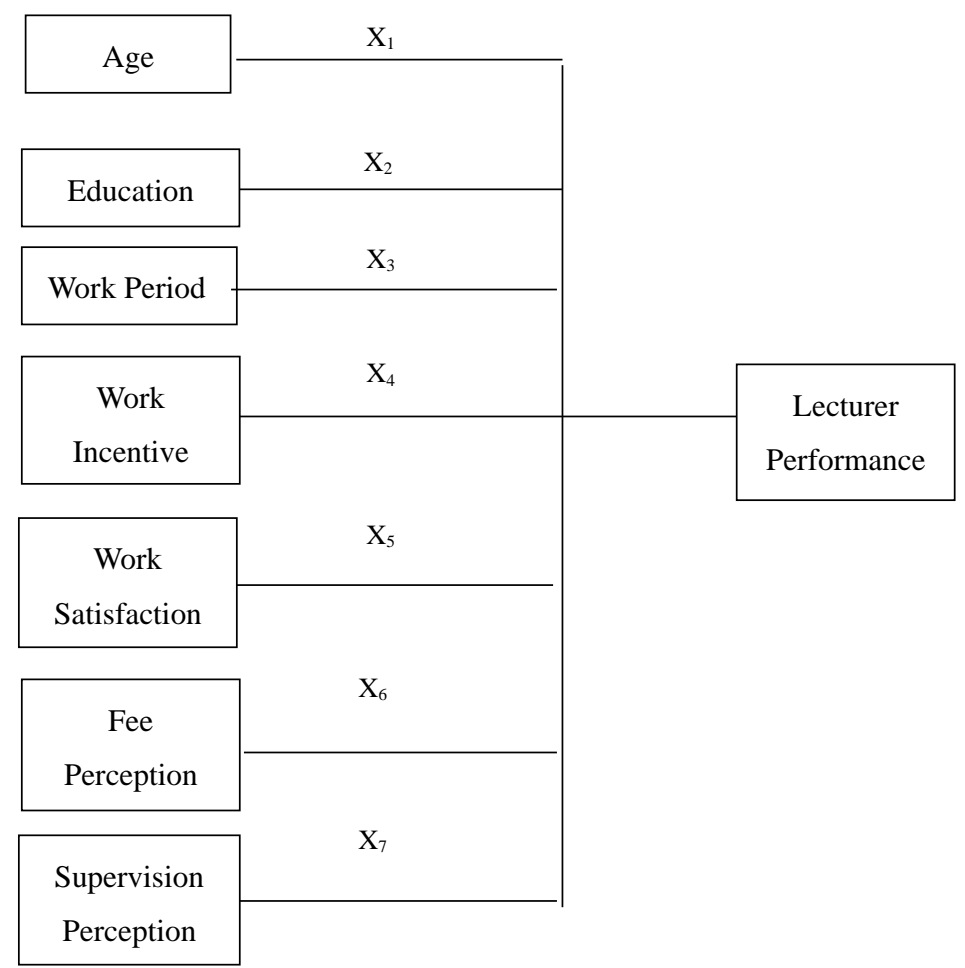

Figure 1. Research Framework

There are some hypotheses of this research, they are:

1. Age influences lecturer performance in performing learning process

2. Education influences lecturer performance in performing learning process

3. Work period influences lecturer performance in performing learning process

4. Work motivation influences lecturer performance in performing learning process

5. Work satisfaction influences lecturer performance in performing learning process

6. Fee perception influences lecturer performance in performing learning process

7. Supervision perception influences lecturer performance in performing learning process

Population, in analytical description research, means generalisation area which consists of object / subject which have certain quality and characteristic and is determined by the researcher to be learned and to be drawn conclusion. Sample, on the other hands, is part of the population (Sugiyono, 2012). The samples, in this research, are four private universities in Bandung city which represent whole private universities in Bandung city in the amount of 392 people.

A good sample should describe the population; thus the writers use non-probability sampling technique in the group of purposive sampling. This technique is a technique in which the characters have been known before based on the population characteristic that the writers need. Regarding to the previous comprehension, this research has 120 samples of questioner. The questioner then becomes the primary data of the research. It refers to some considerations related to the time, personnel, and fund. The writers distribute 120 questioners to four private universities in Bandung city but only 102 questioners return. It means that the 
samples of the research are 102 respondents.

The instrument of the research is questioner which is used before by the previous research "Lecturer Performance Factors" (Mundarti, 2007). The questioner is used to appraise lecturer performance in learning process, age, education, work period, work satisfaction, fee perception, and supervision perception.

\section{Result and Discussion}

The investigated variables in this research are dependent variable and independent variable. The investigated dependent variables are age, education, work period, work motivation, fee perception, and supervision perception, meanwhile the investigated independent variable is performance in performing learning process. The analysed data is the data that is collected from research result then it is processed by SPSS21 software.

$$
\begin{array}{rllllll}
\mathbf{Y} & =\mathbf{2 3 , 2 9 1 + 0 , 0 6 9 X}+\mathbf{0 , 5 7 1} \mathbf{X 2 + 0 , 0 3 4 X 3 + 1 , 1 8 5} \mathbf{X 4 + 0 , 5 4 4 X 5 - 0 , 3 8 3 X 6 + 0 , 2 0 9} \mathbf{X 7} \\
\mathrm{Se} & =(10,228)(0,110)(3,185) & (0,160) & (0,140) & (0,250) & (0,089) & (0,112) \\
\text { t-Stat } & =(2,277)(0,628)(0,179) & (0,212) & (8,261) & (2,177) & (-4,305) & (1,870) \\
\mathrm{R}^{2} & =0,581 & & & & & \\
\text { Adjst } \mathrm{R}^{2} & =0,550
\end{array}
$$

Where:

$\mathrm{Y}=$ Performance in performing learning process

$\mathrm{X}_{1}=$ Age

$\mathrm{X}_{2}=$ Education

$\mathrm{X}_{3}=$ Work period

$\mathrm{X}_{4}=$ Work motivation

$\mathrm{X}_{5}=$ Work satisfaction

$\mathrm{X}_{6}=$ Fee perception

$\mathrm{X}_{7}=$ Supervision perception

Regression equation above describes some statements such as:

1) Regression equation constant is 23,291 which means that when age, education, work period, work motivation, fee perception, and supervision fee do not exist (in the amount of 0 ), thus the result of performance in performing learning process is in the average of 23,291 in one unit.

2) $X_{1}$ (age) coefficient variable amount is 0,069 . It means that when age increases in the average of one unit, performance in performing learning process will increase in the average of amount of 0,069 in one unit accordingly.

3) $\mathrm{X}_{2}$ (education) coefficient variable amount is 0,571 . It means that when education increases in the average of one unit, performance in performing learning process will increase in the average of amount of 0,571 in one unit accordingly.

4) $X_{3}$ (work period) coefficient variable amount is 0,034 . It means that when work period increases in the average of one unit, performance in performing learning process will increase in the average of amount of 0,034 in one unit accordingly. 
5) $\mathrm{X}_{4}$ (work motivation) coefficient variable amount is 1.185 . It means that when work motivation increases in the average of one unit, performance in performing learning process will increase in the average of amount of 1,185 in one unit accordingly.

6) $\mathrm{X}_{5}$ (work satisfaction) coefficient variable amount is 0,554 . It means that when work satisfaction increases in the average of one unit, performance in performing learning process will increase in the average of amount of 0,554 in one unit accordingly.

7) $\mathrm{X}_{6}$ (fee perception) coefficient variable amount is $-0,383$. It means that when fee perception increases in the average of one unit, performance in performing learning process will decrease in the average of amount of 0,069 in one unit accordingly.

8) X7 (supervision perception) coefficient variable amount is 0,209 . It means that when supervision perception increases in the average of one unit, performance in performing learning process will increase in the average of amount of 0,209 in one unit accordingly.

This research employs two-ways testing hypothesis. The degree of assurance is $95 \%$ or the residue is $5 \%(\alpha=5 \%)$.

The result of the research reveals some factors that influence lecturer performance to perform learning process in private universities in Bandung city. The data analysis says that $\mathrm{X}_{1}$ variable (age) influenced in the amount of 0,$069 ; \mathrm{X}_{2}$ variable (education) influenced in the amount of 0,$571 ; \mathrm{X}_{3}$ variable (work period) influenced in the amount of 0,$034 ; \mathrm{X}_{4}$ variable (work motivation) influenced in the amount of 1,$185 ; \mathrm{X}_{5}$ variable (work satisfaction) influenced in the amount of 0,$554 ; \mathrm{X}_{6}$ variable (Fee perception) influenced in the amount of $-0,38 ; X_{7}$ variable (supervision perception) influenced in the amount of 0,209.

The result of this research shares the result of previous research. Syamsul Bahri (2009), in his research, states that there are significant influences of lecturer performance such as teaching ability and work environment. Albanese (1978), furthermore, mentions four main factors of performance, for instance, motivation, ability, role perception and organization situational.

The result of this research, in addition, shows positive influence and negative influence of each analysed variables. The orders of variables, big to small influence, that influence lecturer performance in performing learning process are work motivation, education, work satisfaction, supervision perception, age and work period. Fee perception, on the other hands, does not influence lecturer performance in performing learning process. The result of the research, in addition, shows negative influence to fee perception.

\section{Conclusion}

The result of the research shows some factors that influence lecturer performance in performing learning process such as work motivation, education, work satisfaction, supervision perception, age and work period. Furthermore, data analysis displays that fee perception does not influence lecturer performance in performing learning process. The orders of the most influencing factors of lecturer performance in performing learning process 
are work motivation, education, work satisfaction, supervision perception, age, work period, and fee perception.

\section{References}

Albanese, R. (1978). Managing toward Accountability for Performance. Homewood, Illinois: Richard D. Irwin. Inc.

Amstrong, M. (1999). The Art of Human Resource Management. Vol 2. $1^{\text {st }}$ Edition. New Delhi: Grest Publishing House

Bahri, S. (2011). Faktor yang Mempengaruhi Kinerja Guru SD di Dataran Tinggi moncong Kabupaten Gowa Provinsi Sulawesi Selatan. Jurnal MEDTEK, 3(2).

Blazey, et al. (2009). Insight to Performance Excellence in Education 2001: An Inside Look at the 2001 Baldrige Award Criteria for Education. Wisconsin: ASQ Quality Press.

Christianingsih, E. (2011). Pengaruh Kepemimpinan Visioner dan Kinerja Dosen terhadap Produktivitas Pendidikan Tinggi. Jurnal Administrasi Pendidikan.

Departemen Pendidikan Nasional. (1990). Peraturan Pemerintah Republik Indonesia No.30 Tahun 1990 Tentang Pendidikan Tinggi. Jakarta: Depdiknas.

Departemen Pendidikan Nasional. (2005). Undang-Undang Nomor 14 Tahun 2005 Tentang Guru dan Dosen. Jakarta: Depdiknas

Ditjen Dikti Depdiknas. (2004). Tanya Jawab Seputar Unit dan Proses Pembelajaran di Perguruan Tinggi. Jakarta: Departemen Pendidikan Nasional

Lembaga Administrasi Negara (LAN). (2004). Modul Sistem Akuntabilitas Kinerja Instansi Pemerintah. (Edisi Kedua). Jakarta.

Marwansyah. (2014). Manajemen Sumber Daya Manusia. Edisi kedua. Bandung: ALFABETA, CV.

Mundarti. (2007). Faktor-faktor yang Mempengaruhi Kinerja Dosen dalam Melaksanakan Proses Belajar Mengajar di Prodi Kebidanan Magelang Politeknik Kesehatan Semarang Tahun Akademik 2005/2006. (Tesis dipublikasikan). Sekolah Pascasarjana Universitas Diponegoro, Semarang, Indonesia.

Robbins, S. P. (2011) Perilaku Organisasi, Edisi Indonesia. Indeks Kelompok Gramedia.

Rohani, A., \& Ahmadi, A. (1999) Pengelolaan Pengajaran. Jakarta: Rineka Cipta.

Smith, A. (1982). Management, Making Organization Perform. New York: McMillan Publishing Co, Inc.

Sugiyono. (2012) Metode Penelitian Pendidikan. Bandung: Alfabeta.

Suparyanto. (2010). Konsep Pengetahuan. [online] Available: http://dr-suparyanto.blogspot.com/2010/07/konsep-kepatuhan.html. (December 13, 2011) 


\section{Copyright Disclaimer}

Copyright for this article is retained by the author(s), with first publication rights granted to the journal.

This is an open-access article distributed under the terms and conditions of the Creative Commons Attribution license (http://creativecommons.org/licenses/by/4.0/). 